\title{
Perceived Organizational Support and Organizational Citizenship Behavior: The Case of Kuwait
}

\author{
Ali H. Muhammad \\ ${ }^{1}$ Department of Management \& Marketing, College of Business, Kuwait University, Safat, Kuwait \\ Correspondence: Ali H. Muhammad, Associate Professor and Chair, Department of Management \& Marketing, \\ College of Business, Kuwait University, P.O.Box 5486 Safat, 13055, Kuwait. Tel: 965-6660-0076. E-mail: \\ ali@cba.edu.kw
}

Received: April 4, 2014

Accepted: April 25, 2014

Online Published: April 30, 2014

doi:10.5430/ijba.v5n3p59

URL: http://dx.doi.org/10.5430/ijba.v5n3p59

\begin{abstract}
This article examines the relationship among perceived organizational support, affective organizational commitment, and employee citizenship behavior in Kuwaiti business organizations. Employees' affective organizational commitment is proposed to mediate the relationship between perceived organizational support and employee citizenship behavior. Data were collected from 261 employees affiliated with 9 Kuwait business organizations. These businesses represented firms in the banking, and financial industries. Results indicate that: (1) perceived organizational support is positively related to affective organizational commitment and (2) affective organizational commitment mediates the relationship between perceived organizational support, and organizational citizenship behavior.
\end{abstract}

Keywords: perceived organizational support, organizational commitment, organizational citizenship behavior

\section{Introduction}

Organizational citizenship behavior (OCB) encompasses all behaviors that are not considered to be part of employee's formal duties in the organization and that contributes to the enhancement of organizational performance (Organ, 1997). Examples of organizational citizenship behavior include fruitful activities such as assisting co-workers in performing work-related tasks, working extra hours without pay, going the extra mile in making a newly appointed employee feel welcome, and abiding by informal codes of conduct established to preserve harmony.

OCB is a multidimensional concept consisting of Help Oriented Behavior and Courtesy (Swaminathan \& Jawaher, 2013). Williams and Anderson (1991) conducted a literature review of studies of organizational citizenship behavior in which they revealed the existence of two kinds of OCBs : (a) OCBO- behaviors that profit the organization on the whole (e.g., preserves and safeguards company's resources, engage in activities that enhance organization's image) and (b) OCBI- actions and activities that serve particular employees and thereby enhance the functioning of the organization (e.g., going the extra mile in making a newly hired fellow employee feel welcome, sharing ideas with co-workers on how to increase their effectiveness and efficiency at work.

Benjamin (2012) points out that at the present time, the world-wide competition, increases the importance of organizational citizenship behavior as a mean for the improvement and utilization of human resources, and for enhancing organizational viability. In showing the benefits of organizational citizenship, Denis Organ (1988) explains that organizational citizenship behavior ensures the efficiency and effectiveness of the organization by fostering creativity, and enhancing flexibility.

The findings of Yperen, Berg, and Willering (1999) indicate that allowing employees to participate in decision-making will make them feel acknowledged and prized which in turn prompts them to reciprocate with organizational citizenship behavior.

Furthermore, the meta-analytic review of 55 studies, conducted by Organ and Ryan (1995), revealed that job satisfaction, perceived justice, organizational commitment, and leader supportiveness are powerful determinates of OCB. More recent research findings, revealed the following variables to be predictors of OCB: job satisfaction (Swaminathan \& Jawaher, 2013), organizational commitment (Benjamin, 2012), trust between employees (Podsakoff, Mackenzie, Moorman, \& Fetter, 1990), job engagement (Ueda, 2012), role clarity (Chahal, \& Mehta, 2011), 
Organizational Justice (Ahmadi, Ahmadi, \& Taverah, 2011), role stressors (Eatough, Change, Miloslavic, \& Johnson, 2011), and leadership style (Lian, \& Tiu, 2012). Within the Middle East, Rasheed, Jehanzeb, and Rasheed (2013) found that job Satisfaction, organizational commitment, role perceptions, fairness perceptions, leadership behavior, and feedback to be associated with the degree of OCB among employees working in the banking sector in Saudi Arabia.

Podsakoff, Makenzie, Paine, and Bachrach (2000) argue that cultural background may influence not only the degree to which OCB is associated with its determinants and consequences, but also the method by which OCB behavior is initiated and through which it influences organizational effectiveness. Despite the numerous studies conducted on organizational citizenship behavior, little is known about this phenomenon beyond the Western context (Farh, Early, \& Lin, 1997).

The present study uses a sample of employees from Kuwaiti work organizations to investigate the method through which OCB is initiated within an Arab culture. More specifically the study examines the relationships among perceived organizational support, affective organizational commitment, and employee citizenship behaviour. The study suggests that perceived organizational support affects employee's citizenship behaviour through affective organizational commitment. In other words, organizational commitment mediates the relationships between perceived organizational support and organizational citizenship behaviour.

\section{Perceived Organizational Support, Affective Organizational Commitment and Work Outcomes}

\subsection{Perceived Organizational Support}

Perceived organizational support (POS) is defined as the degree to which employees believe that their organizations appreciate their contributions and care about their well-being and (Eisenberger et al., 1986 and Eisenberger at al., 2001) found positive relationship between POS and job performance through their empirical study. Jokisaari, and Nurmi (2009) examined the role played by newcomers' perceived supervisor support on socialization outcomes in organizations. Their study revealed that steeper the decrease in perceived supervisor support during the first 6 to 21 months after employment, slower the increase in salary over time and more the decrease in job satisfaction and role clarity (Jokisaari, and Nurmi, 2009). This decrease in role clarity, that indicates the lack of knowledge regarding job goals and requirements, is in turn related to a decrease in job performance (e.g., Tubre \& Collins, 2000). Logan and Ganster's study (2007) concluded that the empowerment among unit managers significantly increased perceptions of maintenance control only for managers who perceived their supervisors as being supportive. Depending on perceived supervisory support, unit performance, archival measures and work attitudes were affected by the intervention. The results showed the importance of supervisor support during implementation of organizational change (Logan and Ganster, 2007). Mitchell (2005) explained that the effect of high performance HR practices on corporate entrepreneurship are mediated by work characteristics as POS. Based on the social exchange theory, a study in biotechnology pharmaceutical enterprises showed that POS played the role of a mediator between high-performance human resources practices and corporate entrepreneurship (Zhang and Jia, 2010).

\subsection{Affective Organizational Commitment}

Mowday et al. (1979) defined commitment as “an employee's belief in and acceptance of an organization's goals and values, a willingness to exert effort on behalf of the organization, and a desire to maintain membership in the organization". Individuals form positive attitudes and psychological attachments with an organization, which postulates in an active relationship between employees and their organization (Mowday et al., 1979).

Meyer (2009) defined commitment as "the internal force that binds an individual to a target (social or nonsocial) and/or to a course of action of relevance to that target". Gong and Chang (2008) explained that high organizational commitment of employees means that they identify with the company and work to achieve its goals. Klein, Molloy, and Brinsfild (2012) reconceptualized commitment by presenting a continuum of psychological bonds, highlighting the distinctiveness of organizational commitment and improving its applicability across several workplace targets. Employees exhibit multiple forms of bonds and psychological attachments in the workplace. Wide range of these bonds have been defined as commitment in the literature, that differentiate them in terms of target and type. Bond target refers to "the specific foci to which a bond is formed" such as supervisors, organization, goals, professional associations, work teams etc., (Meyer \& Herscovitch, 2001; Becker, 1992). Bond type refers to "how the bond is experienced", such as calculative, alienative, and moral bonds (Etzioni, 1961), or affective, continuance and normative mindsets (Meyer and Allen, 1991).

Many scholars have differentiated between continuance, affective, and normative organizational commitments 
(Meyer \& Allen, 1991). Affective commitment is led by feelings of self-determination and intrinsic motivation and self-determination, continuance and normative behavior involve feelings of pressure and obligation to be attached (Meyer, Becker, \& Vandenberghe, 2004). Compared with continuance and normative commitment, affective commitment is most associated with positive organizational outcomes such as organizational citizenship behavior, job performance, and attendance, and employee's outcomes such as less tress, absenteeism, turnover, and work-family conflict (Meyer et al, 2002; Hausknecht, Hiller, and Vance, 2008).

\subsection{POS and Organizational Commitment}

Numerous studies have demonstrated the effect of POS on organizational commitment. According to the social exchange theory, employees reciprocate what they receive; they reciprocate POS by committing to the organization (Blau, 1964; Tsui and Wu, 2005; Blau, 1964; Emerson, 1976; Homans, 1958). Scholars have drawn on this theory to study how perceived organizational support explains the development of affective organizational commitment (Rhoades \& Eisenberger, 2002). Employees that perceive that the organization cares about their well-being, reciprocate and develop an emotional bond with the organization. (Grant, Dutton, and Rosso, 2008). Reflecting social exchange, perceived organizational support was found to influence organizational commitment (Shore \& Wayne, 1993).

According to Coyle-Shapiro et al. (2002), research has consistently proved that organizational policies that treat employees favorably and value their contributions positively affect affective organizational commitment exerted by employees.

Eisenberger et al. (1986) found that more an employee perceives the organization is committed to him/her, more he/she is committed to the organization. Rhodes and Eisenberger (2002) found that POS decreases turnover intentions and absenteeism, and it increases performance, job satisfaction, and organizational commitment. Organizational support theory postulates that organizational feedback like receiving rewards, influences how newcomers perceive and attach to the organization (Rhodes \& Eisenberger, 2002). Grant, Dutton, and Rosso (2008) found that employee support programs reinforce affective organizational commitment since employees identify company actions as caring. A study conducted by Farndale et al. (2011) shows that employees who perceive that they have the opportunity to voice their opinions regarding changes and influence decision-making, exhibit high commitment to the organization.

Becker \& Huselid (2006) linked HR practices with commitment by explaining that they may create bonds with organization. Klein, Molloy, and Brinsfild (2012) showed that HR practices along with climate and culture are key organizational factors that influence commitment.

Profit-sharing plans (PSP) implementation could also be interpreted as POS or as a sign that the organization cares about the well-being of its employees and values their work (Coyle-Shapiro et al., 2002). Employees are more likely to reciprocate with affective commitment (Eisenberger, Huntington, \& Sowa, 1986; Eisenberger, Fasolo, \& DavisLaMastro, 1990; Rhoades, Eisenberger, \& Armelli, 2001). A positive relationship that links PSP to organizational commitment was found to be strongest in small firms (Bayo-Moriones, and Larraza-Kintana, 2009), and a positive relationship that links favorable perception of PSP and organizational commitment was found (Coyle-Shapiro et al. 2002) to be strong.

Hypothesis 1. Perceived organizational support will be positively related to affective organizational commitment in Kuwaiti business firms.

\subsection{Organizational Citizenship Behavior}

Organizational citizenship behavior (OCB) encompasses all behaviors that are not considered to be part of employee's formal duties in the organization and that contributes to the enhancement of organizational performance (Organ, 1997). Examples of organizational citizenship behavior include fruitful activities such as assisting co-workers in performing work-related tasks, working extra hours without pay, going an extra mile in making a newly appointed employee feel welcomed, and abiding by informal codes of conduct established to preserve harmony.

OCB is multidimensional in orientation and application in OB literature about OCB. While examining the OCB literature, Podsakoff et al., (2000), found more than 30 dimensions of OCB. According to (Organ et al., 2006), two of the most commonly-cited OCB dimensions are altruism and compliance. Altruism is defined as the discretionary helping behaviors, which benefit specific individuals, whereas compliance refers to the cooperative behaviors that 
help increased efficiency.

Williams and Anderson (1991) conducted a literature review of studies of organizational citizenship behavior in which they revealed the existence of two kinds of OCBs : (a) OCBO- behaviors that profit the organization as a whole (e.g., preserves and safeguards company's resources, engage in activities that enhance organization's image) and (b) OCBI- actions and activities that serve particular employees and thereby enhance the functional corporate culture of the organization (e.g., going an extra mile in making a newly hired fellow employee feel welcomed, sharing ideas with co-workers on how to increase their effectiveness and efficiency at work.

\subsection{Perceived Organizational Support (POS) and Organizational Citizenship Behavior (OCB)}

Several studies have found a relationship between POS and OCB. According to Rhoades and Eisenberger (2002), POS assures employees of the organization's willingness to support them and fulfill their socio emotional needs; in turn, employees tend to commit to work for the organization's best interests. This is a representation of the social exchange theory (Blau, 1964; Emerson, 1972). According to Coyle-Shapiro and Conway (2005), good perceived organizational treatment motivates employees to increase their efforts in helping the achievement of organizational goals. Similar to this view, employees tent to reciprocate POS by performing better on the job (Rhoades \& Eisenberger, 2002).

Four HR practices - (participation, performance management process, involvement in decision making, and promotional opportunities) - were found to influence employees commitment to customers and their OCB. This relationship was mediated by POS, since these four HR practices sent signals to employees that they were being appreciated and valued. In turn, employees reciprocated this by going beyond their job responsibilities to deliver better output and results (Gavino, Wayne, and Erdogan, 2012). Another study of HRM practices at the workplace level found that through an effect on perceived job influence/discretion, HRM practices positively affected OCB. For instance, a significant relationship was also found between these HRM practices and POS, indicating that these practices were seen by employees as the organization's care and concern for their welfare (Snape and Redman, 2010).

In the service industry, POS was also linked with OCB. Multilevel analyses of data from hotels found that service oriented OCB partially mediated the relationship between high-performance HR practices and performance (Sun, Aryee, and Law, 2007). Sun, Aryee and Law (2007) also explained that high-performance HR practices fostered employees' perceived organizational support.

Results of a study testing i-deals, which are special negotiated arrangements with employers, reveal stronger positive relationships between i-deals and OCB for employees with low leader-member exchange or team-member exchange (Anand et al., 2010).

2.6 Perceived Organizational Support (POS), Affective Organizational Commitment, and Organizational Citizenship Behavior $(O C B)$

Numerous scholarly studies have supported a relationship between POS and OCB, mediated by organizational commitment. A study of physician employees showed that POS leads to better work performance when organizational identification is high (Hekman, Bigley, and Hereford, 2009); as more physicians identify with their organization and profession, the more they tend to reciprocate POS by increasing performance. Ellemers, DeGilders, and Haslam (2004) explained that individuals are generally more likely to contribute to a positive reciprocity when they experience feeling of strong identification with their group in order to ensure the continued receipt of benefit from that group. Prior studies revealed that social identification influences extra-role performance or OCB, organizational commitment, job involvement and satisfaction (Riketta, 2005; Wright \& Bonett, 2002; van Dick et al., 2004).

Gong and Chang (2008) found that when organizations provide career advancement opportunities, employees respond with higher organizational commitment, firm performance, and OCB. They also found that when organizations provide employment security, employees also respond with increase organizational commitment, but not with OCB or higher performance (Gong and Chang, 2008). Moreover, employment security may be seen as a form of organizational support, which may lead to an increase in organizational commitment (Allen, Shore, \& Griffeth, 2003). And in turn, affective organizational commitment is a key determinant of OCB (Harrison et al., 2006; Meyer et al., 2002).

According to Kirkman et al. (2009), social identity theory can explain the effect of transformational leadership from 
the standpoint of belonging to organizations, which in turn translates to better task performance and OCB when employees are motivated to go beyond their job requirements to serve the organization. Transformational leaders were found to generate OCB by increasing employees' view of importance and impact of their job and their sense of personal meaning (Alge, Ballinger, Tangirala, \& Oakley, 2006)

Intrinsic motivation, job involvement, satisfaction and most importantly job engagement mediated relationships between POS, and two job performance dimensions which were OCB and task performance (Rich, Lepine, and Crawford, 2010). Engagement was defined as the investment of the employee's self into a role, which makes it close in concept with organizational commitment. However, Kuvaas (2008) found that affective commitment, organizational support, and organizational justice did not mediate the positive relationship between 'developmental human resource practices' and performance. Zhang, Wang, and Shi (2012) examined the congruence effect of leader and follower proactive personality on leader member exchange (LMX) quality. Their findings revealed that when employee's personality was lower than their leader', asymmetrical incongruence effects were present and followers had lower-quality LMX and inferior work outcomes. Higher-quality LMX was also associated with higher levels of performance, affective organizational commitment, and job satisfaction (Zhang, Wang, and Shi, 2012).

Hypothesis 2: Affective organizational commitment will mediate the relationship between perceived organizational support and organizational citizenship behavior directed to the individual (OCBI) in Kuwaiti business firms.

Hypothesis 3: Affective organizational commitment will mediate the relationship between perceived organizational support and organizational citizenship behavior directed at the organization (OCBO) in Kuwaiti business firms

\subsection{Perceived Organizational Support (POS), Affective Organizational Commitment, and Job Satisfaction}

Job satisfaction refers to an individual's general attitude toward his or her job (Singh \& Rhodes, 1994). Perceived Organizational support may be related to job satisfaction because feeling of confidence in the organization will affect employee's general perception that the organization values his contributions and cares about his well-being (e.g. POS) and, perceived organizational support should contribute to employees' overall job satisfaction by meeting their socioemotional needs, increasing their performance-reward expectancies, and signalling to them the availability of aid when needed (Rhoades \& Eisenberger, 2002). Previous research findings indicate that organizational commitment is both a consequence of perceived organizational support (Eisenberger et al. 1997) and a determinate of job satisfaction (Riggle, Edmondson, Hansen, 2009). Numerous studies have shown affective organizational commitment and job satisfaction to be closely associated (Iverson and Roy, 1994; Mathieu \& Hamel 1989; Michaels, 1994). Hence, the following hypothesis is proposed:

Hypothesis 4. Affective organizational commitment will mediate the relationship between perceived organizational support and job satisfaction in Kuwaiti business firms.

\section{Methodology}

\subsection{Participants and Procedures}

This study was conducted in nine business organizations in the State of Kuwait. The data were collected using self-administered questionnaires. A total of 350 employees, working in supervisory and non-supervisory positions, were surveyed. This survey methodology yielded a $74 \%$ response rate $(\mathrm{N}=261)$. Out of total participants, $53.6 \%$ were male, $75 \%$ were 40 years or younger, $74 \%$ had worked for the organization 10 years or less, and the entire sample consisted of Arab employees.

\subsection{Measures}

Since most of the respondents did not have a good command of English, the questionnaire was administered in Arabic. In order to check consistency between the English and Arabic versions of the questionnaire, the process of back-translation was used. Table 1 includes the items and sources of the instruments used in in our study. 
Table 1. Measures

\begin{tabular}{|c|c|c|}
\hline Variable & Source & Statements \\
\hline $\begin{array}{l}\text { Perceived } \\
\text { organizational } \\
\text { support }\end{array}$ & $\begin{array}{l}\text { Rhoades, } \\
\text { Eisenberger, and } \\
\text { Armeli, (2001) }\end{array}$ & $\begin{array}{l}\text { 1. My organization really cares about my well-being. } \\
\text { 2. My organization strongly considers my goals and values. } \\
\text { 3. My organization shows little concern for me. (R) } \\
\text { 4. My organization cares about my opinions. } \\
\text { 5. My organization is willing to help me if I need a special favor. } \\
\text { 6. Help is available from my organization when I have a problem. } \\
\text { 7. My organization would forgive an honest mistake on my part. } \\
\text { 8. If given the opportunity, my organization would take advantage } \\
\text { of me. (R). }\end{array}$ \\
\hline $\begin{array}{l}\text { Affective } \\
\text { organizational } \\
\text { commitment }\end{array}$ & $\begin{array}{l}\text { Allen and Meyer } \\
(1990)\end{array}$ & $\begin{array}{l}\text { 1. I feel personally attached to my organization. } \\
\text { 2. I feel a strong sense of belonging to my organization. } \\
\text { 3. I am proud to tell others I work at my organization. } \\
\text { 4. Working at my organization has a great deal of personal meaning } \\
\text { to me. } \\
\text { 5. I would be happy to work at my organization until I retire. } \\
\text { 6. I really feel that problems faced by my organization are also my } \\
\text { problems. }\end{array}$ \\
\hline OCBI & $\begin{array}{l}\text { Lee and Allen } \\
(2002)\end{array}$ & $\begin{array}{l}\text { 1. Willingly give your time to help others who have work-related } \\
\text { problems. }\end{array}$ \\
\hline
\end{tabular}

2. Adjust your work schedule to accommodate other employees' requests for time off.

3. Go out of the way to make newer employees feel welcome in the work group.

4. Assist others with their duties.

OCBO

1. Attend functions that are not required but that help the organizational image.

2. Defend the organization when other employees criticize it.

3. Offer ideas to improve the functioning of the organization.

4. Take action to protect the organization from potential problems.

Job Emerson's (2013)

1. Compared to what you think it should be, how satisfied are you with the type of work you currently do"?

2. Compared to what you think it should be, what is your current overall level of satisfaction with your job?,

3. Compared to what you think it should be, how satisfied are you with the amount of work that you currently do?

3.3 Perceived Organizational Support (POS)

Eight-items of POS develped by Rhoades, Eisenberger, and Armeli, (2001) were adopted by our study. Illustrative items are: "My organization is welling to help me if I need a special favor", "My organization would forgive an honest mistake on my part", "If given the opportunity, my organization would take advantage of me (R)"; "My organization shows little concern for me (R)"; Ratings were made on a five-point Likert type scale that ranged from 1 ("Strongly disagree) to 5 ("strongly agree"). The Cronbach's coefficient alpha for this eight-item scale was 0.70.

\subsection{Affective Organizational Commitment}

Affective organizational commitment was measured with a six-item scale derived from Allen and Meyer's (1990) study. The items were: (1) I feel personally attached to my organization; (2) I feel a strong sense of belonging to my organization; (3) I am proud to tell others I work at my organization; (4) Working at my organization has a great deal of personal meaning to me; (5) I would be happy to work at my organization until I retire; and (6) I really feel that problems faced by my organization are also my problems. Ratings were made on a five-point Likert-type scale that ranged from 1 ("Strongly disagree") to 5 ("strongly agree"). The Cronbach's coefficient alpha for this four-item scale was 0.71 .

\subsection{Organizational Citizenship Behavior}

Organizational citizenship behavior directed to the individual (OCBI) and organization (OCBO) was each measured by employing items developed by Lee and Allen (2002). Participants responded using a five-point Likert-type scale with anchors (1) never to (5) always. A sample item from the OCBI scale is, "Willingly give your time to help others who 
have work-related problems" and a sample item from the OCBO scale is, "Take action to protect the organization from potential problems". The Cronbach coefficient alpha for OCBI and OCBO were $0.73,0.72$ respectively.

\subsection{Job Satisfaction}

Job satisfaction was measured using three items from Emerson's (2013) scale designed to measure employees' satisfaction with their job. These items are, "Compared to what you think it should be, how satisfied are you with the type of work you currently do"? Compared to what you think it should be, what is your current overall level of satisfaction with your job?, and "Compared to what you think it should be, how satisfied are you with the amount of work that you currently do? Ratings were made on a five-point Likert-type scale with anchors (1) not at all satisfied to (5) very satsfied. The Cronbach coefficient alpha for this three-item scale was 0.80 .

\section{Analyses and Results}

Descriptive and inferential statistical analyses were used to analyze the data in this study. The range of possible values, means, and standard deviations of the variables analyzed in this study are illustrated in Table 2.

Table 2. Descriptive statistics $(\mathrm{N}=358)$

\begin{tabular}{lllll}
\hline Variable & Min & Max & Mean & SD \\
\hline POS & 13 & 36 & 24.62 & 4.67 \\
\hline COM (Commitment) & 7 & 28 & 18.45 & 4.19 \\
\hline OCBI & 6 & 20 & 12.40 & 3.09 \\
\hline OCBO & 6 & 19 & 12.28 & 2.88 \\
\hline JS (Job satisfaction) & 4 & 15 & 9.33 & 2.54
\end{tabular}

To investigate the degree of correlation between different research variables shown in Table 2, measure of correlation was computed and tested for significance. Table 3 presents correlations and reliability coefficients, where applicable, for all research variables. The results in Table 3 indicate that perceived organizational support is positively associated with affective organizational commitment $(\mathrm{P}=0.00)$, job satisfaction $(\mathrm{P}=0.00), \mathrm{OCBO}(\mathrm{P}=0.00)$, and OCBI $(\mathrm{P}=0.00)$.

Table 3. Spearman's correlations coefficients and reliabilities

\begin{tabular}{lllll}
\hline & COM & OCBI & OCBO & JS \\
\hline POS & $.49^{*}$ & $.18^{*}$ & $.36^{*}$ & $.41^{*}$ \\
\hline COM (Commitment) & & $.42^{*}$ & $.29^{*}$ & $.58^{*}$ \\
\hline OCBI & & & $.33^{*}$ & $.31^{*}$ \\
\hline OCBO & & & $.25^{*}$ \\
\hline JS (Job satisfaction) & & & \\
\hline
\end{tabular}

* Correlation is significant at 0.01 level.

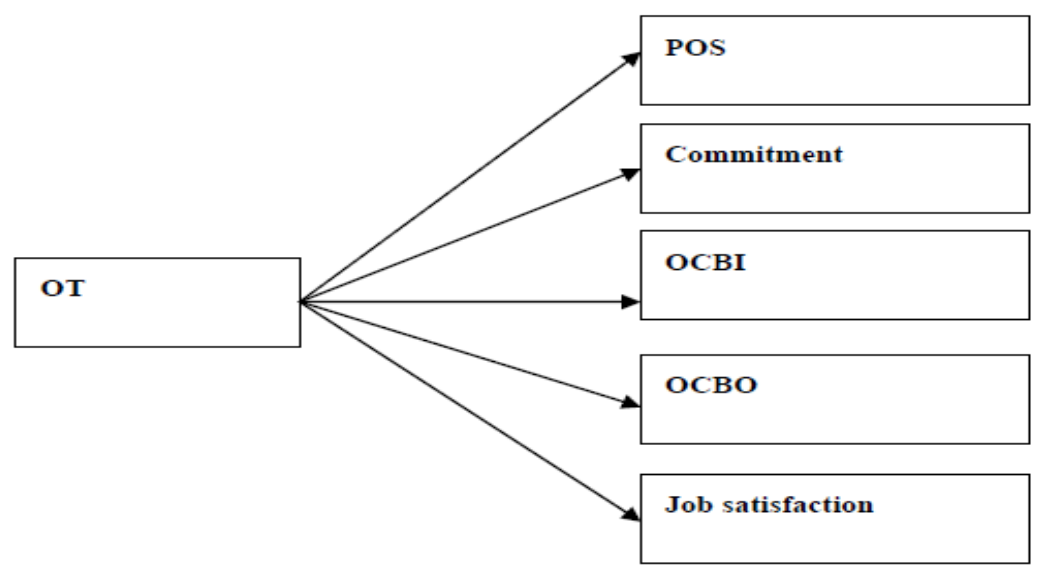

Figure 1. The casual relationships between perceived organizational support and work outcomes 
Table 4. Path coefficients and their significance

\begin{tabular}{lllll}
\hline Research Hypotheses Paths & Coefficient & t-value & p-value \\
\hline $\mathrm{POS} \longrightarrow$ & Commitment & 0.86 & 8.53 & 0.00 \\
\hline $\mathrm{POS} \longrightarrow$ & OCBI & 0.47 & 5.55 & 0.00 \\
\hline $\mathrm{POS} \longrightarrow$ & OCBO & 0.51 & 5.72 & 0.00 \\
\hline $\mathrm{POS} \longrightarrow$ & Satisfaction & 0.70 & 9.61 & 0.00
\end{tabular}

Hypotheses were tested using Structural Equation Modeling (SEM) and path analysis. LISREL computer software was used to perform the structural equation analysis. Data was fitted against several competitor models. The most reasonable model provided GFI (goodness of fit index) $=86 \%$ and RMR (root mean square residual) $=0.07$. Figure 1 illustrates the direct relationships between perceived organizational support and work outcomes. Results of path analysis presented in Table 4 indicate that there is a significant positive direct effect of perceived organizational support on commitment $(\mathrm{t}=8.53, \mathrm{P}=0.00)$. This result provides support for hypothesis 1 . Furthermore, results in Table 4 show a significant direct positive effect of perceived organizational support on each of the work outcomes as follows: satisfaction $(\mathrm{t}=9.61, \mathrm{P}=0.00)$, OCBI $(\mathrm{t}=5.55, \mathrm{P}=0.00)$, OCBO $(\mathrm{t}=5.72, \mathrm{P}=0.00)$. It would be of interest to investigate the above relationships in the presence of commitment as a moderator as shown in Figure 2.

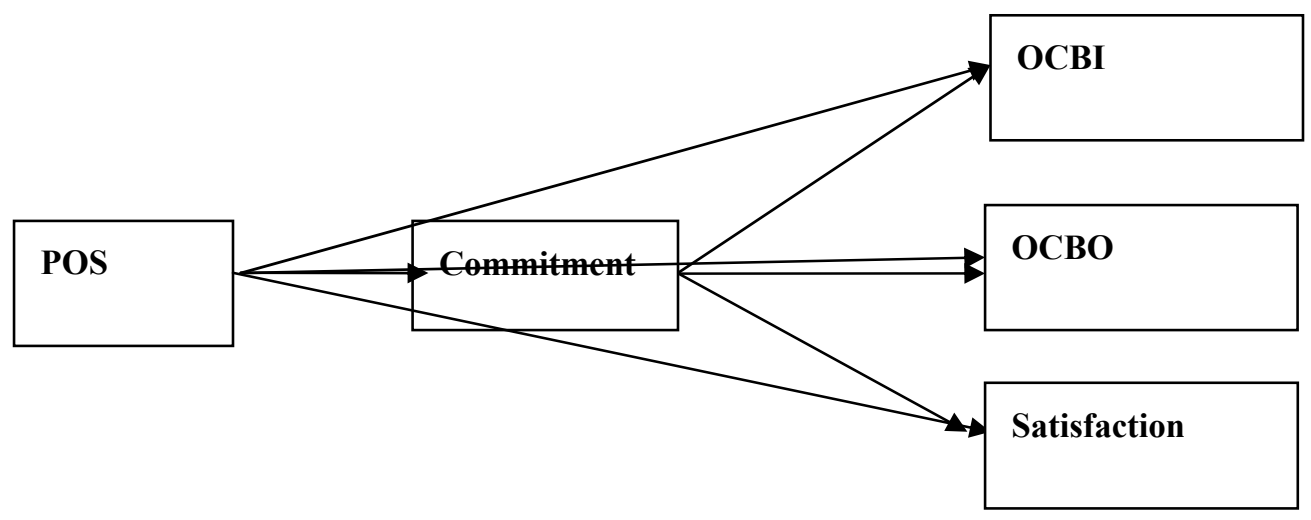

Figure 2. The relationships between POS, Commitment, and work outcomes

Table 5. Structural equation modeling

\begin{tabular}{ll}
\hline OCBI & $=-0.24 *$ POS \\
\hline OCBO & $=0.32 *$ POS \\
\hline Satisfaction & $=0.03 *$ POS \\
\hline Commitment & $=0.70 *$ POS \\
\hline OCBI & $=0.75 *$ Commitment \\
\hline OCBO & $=0.22 *$ Commitment \\
\hline Satisfaction & $=0.74 *$ Commitment
\end{tabular}

Table 6. Path coefficients and their significance

\begin{tabular}{lllll}
\hline Research Hypothesis & Path Coefficients & t-value & P-value \\
\hline $\mathrm{POS} \longrightarrow$ & -0.24 & -1.08 & 0.85 \\
\hline $\mathrm{POS} \longrightarrow$ & 0.32 & 2.52 & 0.00 \\
\hline $\mathrm{POS} \longrightarrow$ & OCBO & 0.03 & 0.33 & 0.37 \\
\hline POS $\longrightarrow$ Satisfaction & 0.70 & 7.31 & 0.00 \\
\hline Commitment $\longrightarrow$ Commitment & $\longrightarrow$ OCBI & 0.75 & 4.74 & 0.00 \\
\hline Commitment $\longrightarrow$ OCBO & 0.22 & 1.77 & 0.03 \\
\hline Commitment $\longrightarrow$ & Satisfaction & 0.74 & 5.77 & 0.00 \\
\hline
\end{tabular}


Table 5 illustrates the mathematical equations of the model in Figure 2. When commitment was included in the structural equation modeling as a moderator as illustrated in Figure 2, the fitted model provided GFI $=88 \%$ and $\mathrm{RMR}=0.06$. Results of path analysis presented in Table 6 indicate a significant positive direct effect of perceived organizational support on commitment $(\mathrm{t}=7.31, \mathrm{P}=0.00)$, and on $\mathrm{OCBO}(\mathrm{t}=2.52, \mathrm{P}=0.00)$, and no significant effect of perceived organizational support on both

OCBI $(\mathrm{t}==1.08, \mathrm{P}=0.85)$ and job satisfaction $(\mathrm{t}=.33, \mathrm{P}=0.37)$.

The results in Table 6 also show that there is direct positive effect of commitment on each of the work outcomes as follows: satisfaction $(\mathrm{t}=5.77, \mathrm{P}=0.00)$, OCBI $(\mathrm{t}=4.74, \mathrm{P}=0.00)$ and $\mathrm{OCBO}(\mathrm{t}=1.77, \mathrm{P}=0.03)$.

Table 7. Direct and indirect effects of perceived organizational support and organizational commitment

\begin{tabular}{|c|c|c|c|c|}
\hline \multicolumn{2}{|l|}{ Research Paths } & Direct Effect & $\begin{array}{l}\text { Indirect } \\
\text { Effect }\end{array}$ & Total Effect \\
\hline $\mathrm{POS} \longrightarrow$ & OCBI & -0.24 & 0.53 & 0.29 \\
\hline $\mathrm{POS} \longrightarrow$ & $\mathrm{OCBO}$ & 0.32 & 0.15 & 0.47 \\
\hline $\mathrm{POS} \longrightarrow$ & Satisfaction & 0.03 & 0.52 & 0.55 \\
\hline $\mathrm{POS} \longrightarrow$ & Commitment & 0.70 & ------ & 0.70 \\
\hline Commitment - & $\longrightarrow$ OCBI & 0.75 & ------- & 0.75 \\
\hline Commitment - & $\longrightarrow \quad \mathrm{OCBO}$ & 0.22 & ------- & 0.22 \\
\hline Commitment - & $\longrightarrow$ Satisfaction & 0.74 & ------ & 0.74 \\
\hline
\end{tabular}

Results in Table 7 show the direct and indirect effects of perceived organizational support and commitment. The direct paths from perceived organizational support to $\mathrm{OCBI}(\mathrm{t}=-1.08, \mathrm{p}=0.85)$, and to job satisfaction $(\mathrm{t}=0.33, \mathrm{p}=0.37)$ are statistically insignificant. However, these relationships become strongly significant via commitment. When commitment is inserted in the model, the t-value for OCBI increases to $3.40(\mathrm{p}=0.00)$, and the $\mathrm{t}$-value for job satisfaction increases to $7.27(\mathrm{p}=0.00)$. Furthermore, Table 7 show that the direct path from perceived organizational support to OCBO is somewhat significant $(\mathrm{t}=2.52)$, and becomes strongly significant via POS $(\mathrm{t}=5.19$, $\mathrm{p}$-values $=0.00)$.

These findings signify the positive influence of commitment on job satisfaction, OCBO, and OCBI. The combined results in Tables 6 and 7 provide support for the moderating role of commitment in the relationships between perceived organizational support and work outcomes, and thus validate research hypotheses 2,3 , and 4 . Table 8 , provides summary statistics regarding the total effect of perceived organizational support on work outcomes in the absence of commitment and when commitment is present.

Table 8. Total effect of POS on work outcomes

\begin{tabular}{lll}
\hline POS & Absence of commitment & Via commitment \\
\cline { 2 - 3 } & Total Casual Effect & Total Casual Effect \\
\hline OCBI & -0.24 & 0.29 \\
\hline OCBO & 0.32 & 0.47 \\
\hline Satisfaction & 0.03 & 0.55 \\
\hline
\end{tabular}

Table 8 clearly signifies the role organizational commitment can play in moderating the relationship between perceived organizational support and work outcomes. Affective organizational commitment tends to significantly increase the effect of perceived organizational support on employees' job satisfaction, and organizational citizenship behavior.

\section{Conclusion, Disscusion, and Managerial Implications}

Using a sample of employees working in Kuwaiti business organizations, the present study provides evidence for the mediating role affective organizational commitment in the relationships between perceived organizational support and organizational citizenship behavior and job satisfaction. Our study examined whether perceived organizational support affects OCB and job satisfaction by influencing an employees' affective organizational commitment, and if this commitment prompts the reciprocation of positive work outcomes. Our results provided support for a relationship between perceived organizational support and affective organizational commitment and between organizational commitment and job satisfaction, and organizational citizenship behavior (OCBI, OCBO). More 
specifically, our results indicate that affective organizational commitment mediates the relationships between perceived organizational support and the three work outcomes (i) job satisfaction, (ii) OCBI, and (iii) OCBO).

The results of this study are consistent with western studies examining the relationships between perceived organizational support and job satisfaction, and organizational citizenship behaviour (Rhoades, \& Eisenberger, 2002). However, the results reported in this paper reveal that the relationships between perceived organizational support and work outcomes are mediated by affective organizational commitment. The model tested suggests that perceived organizational support affects work outcomes by influencing affective organizational commitment, which in turn prompts employees to reciprocate with positive work outcomes. These exchange relationships are in line with the propositions of the Social Exchange Theory (Blue, 1964), that refers to the voluntary actions of individuals that are motivated by the returns they are expected to bring and typically do in fact bring from others.

\subsection{Managerial Implications}

There are a number of important theoretical and practical implications of our research findings. The findings offer an explanation for how perceived organizational support may affect employees' work attitudes and behaviors. The apparent mechanism is that perceived organizational support affects the degrees of employees' affective commitment to their organization, and this commitment creates a climate in which the employees are likely to reciprocate with positive work outcomes. Second, our research results support the role of perceived organizational support as an antecedent to affective organizational commitment. Other possible antecedents of organizational commitment include role stressors, leadership style, organizational justice (Concha, 2009; Ahmad, 2010; De Cuyper, 2009; Hulpia \& Hester, 2009).

Our research results also show that employees' attitudes and behaviors can be regarded as the results of a social exchange process in which employee's citizenship behavior is a consequence of organization's contributions and care about their well-being. As part of the practical implications of the present study, organizations interested in fostering positive work outcomes must ensure their policies and practices reinforce employees' perceptions of organizational support. Furthermore, perceptions of organizational support levels need to be monitored regularly within the organization.

Finaly, mediating role of affective organizational commitment between perceived organizational support and positive work outcomes was clearly established. While POS can be measured by utilizing well established measures (Eisenberger et al., 1997), it may not provide clear indication why such POS is low or high, through such measures, if POS is found to be low or less than satisfactory, management will be faced with what actions need to be taken to strengthen the POS. Our study suggests that management should focus on developing and effectively implementing various organizational support mechanisms. Through such an approach, POS can be enhanced which in turn leads to positive work outcomes.

\subsection{Limitations and Future Research}

The current study is not without limitations. First, the cross-sectional research design of the study prevents any interpretation of causality among the variables. In spite of the fact that there is theoretical and empirical backing for the model presented in this paper, one cannot rule out alternative explanations for the findings. My suggestions for future research efforts examining the relationships between perceived organizational support and organizational citizenship behavior is to use longitudinal research designs. In a longitudinal study it may be possible to observe over time if perceived organizational support taken at one point is related to positive attitudes of organizational commitment and work outcomes at a later point. This type of research design will make it possible to unambiguously determine the causal sequence from perceived organizational support to organizational commitment and work outcomes.

Second, the use of self-reported data, in testing the model, suggests that the reported results could possibly be influenced by method variance, necessitating the deployment of controls for various potential biasing effects.

\section{Acknowledgment}

The author is grateful to the research department at Kuwait University for financially supporting this study under the code number IM01/13

\section{References}

Ahmad, N. (2009). Empowerment, job satisfaction and organizational commitment: A comparative analysis of nurses working in Malaysia and England. Journal of Nursing Management, 17(7), 822-32. 
Ahmadi, F., Ahmadi, S., \& Taverah, N. (2011). Survey relationship between organizational justice and organizational citizenship behavior of food product firms in Kurdestan province. Interdisciplinary Journal of Contemporary Research in Business, 2(10), 272-281.

Alge, B. J., Ballinger, G. A., Tangirala, S., \& Oakley, J. L. (2006). Information privacy in organizations: Empowering creative and extrarole performance. Journal of Applied Psychology, 91, 221-232.

Allen, D. G., Shore, L. M., \& Griffeth, R. W. (2003). The role of perceived organizational support and supportive human resource practices in the turnover process. Journal of Management, 29, 99-118.

Anand, S., Vidyarthi, P.R, Linden, R.C., \& Rousseau, D.M. (2010). Good citizens in poor-quality relationships: Idiosyncratic deals as a substitute for relationship quality. Academy of management journal, 53(5), 970-988.

Ashforth, B. E., \& Mael, F. (1989). Social identity theory and the organization. Academy of Management Review, 14, 20-39.

Bayo-Moriones, A., \& Larraza-Kintana, M. (2009). Profit-sharing plans and affective commitment: Does the context matter?. Human Resource Management, 48(2), 207-226. http://dx.doi.org/10.1002/hrm.20276

Becker, B. E., \& Huselid, M. A. (2006). Strategic human resources management: Where do we go from here? Journal of Management, 32, 898-925. http://dx.doi.org/10.1177/0149206306293668

Becker, T. E. (1992). Foci and bases of commitment: Are they distinctions worth making? Academy of Management Journal, 35, 232-244. http://dx.doi.org/10.2307/256481

Benjamin, A. (2012). The Influence of Affective Commitment on Citizenship Behavior and Intention to Quit among Commercial Banks' Employees in Nigeria. Journal of Management and Sustainability, 2(2), 54-68.

Blau, P. M. (1964). Exchange and power in social life. New York: Wiley.

Cammann, C., Fichman, M., Jenkins, G.D., \& Klesh, J.R. (1983). Assessing the attitudes and perceptions of organizational members. In Seashore, S.E., Lawler, E.E. III, Mirvis, P.H. and Cammann, C. (Eds.), Assessing Organizational Change: A Guide to Methods, Measures, and Practices (pp. 71-138). Wiley, New York, NY.

Chahal H., \& Mehta, S. (2011). Antecedents and consequences of organizational citizenship behavior. Journal of Services Research, 10(2), 25-44.

Chang, C-H., Rosen, C.C., \& Levy, P.E. (2009). The relationship between perceptions of organizational politics and employee attitudes, strain, and behavior: A meta-analytic examination. Academy of Management Journal, 52(4), 779-801. http://dx.doi.org/10.5465/AMJ.2009.43670894

Concha, A. (2009). The impact of role stress on workers' behaviour through job satisfaction and organizational commitment. International Journal of Psychology, 44(3), 187-194.

Coyle-Shapiro, J. A.-M., \& Conway, N. (2005). Exchange relationships: Examining psychological contracts and perceived organizational support. Journal of Applied Psychology, 90, 774-781.

Coyle-Shapiro, J.A.-M., Morrow, P. C., Richardson, R., \& Dunn, S R. (2002). Using profit sharing to enhance employee attitudes: A longitudinal examination of the effects on trust and commitment. Human Resource Management, 4l(4), 423-439. http://dx.doi.org/10.1002/hrm.10052

Cropanzano, R., \& Mitchell, M. S. (2005). Social exchange theory: An interdisciplinary review. Journal of Management, 31(6), 874-900. http://dx.doi.org/10.1177/0149206305279602

De Cuyper, N. (2009). Job insecurity and employability in fixed-term contractors, agency workers, and permanent workers: Associations with job satisfaction and affective organizational commitment. Journal of Occupational Health Psychology, 14(2), 193-207. http://dx.doi.org/10.1037/a0014603

Doney, P.M., Cannon, J.P., \& Mullen, M.R. (1998). Understanding the influence of national culture on the development of trust. Academy of Management Review, 23(3), 601-20.

Dyne, L. V., Graham, J. W., \& Dienesch, R. M. (1994). Organizational citizenship behavior: Construct redefinition, measurement, and validation. Academy of Management Journal, 4, 705-802.

Eatough, E., Change, C., Miloslavic, S., \& Johnson, R. (2011). Relationships of role stressors with organizational citizenship behavior: A meta-analysis. Journal of Applied Psychology, 96(3), 619-632.

Eisenberger, R., Armeli, S., Rexwinkel, B., Lynch, P. D., \& Ellemers, N., DeGilders, D., \& Haslam, S. A. (2004). Motivating individuals and groups at work: A social identity perspective on leadership and group performance. 
Academy of Management Review, 29, 459-478.

Eisenberger, R., Fasolo, P., \& Davis-LaMastro, V. (1990). Perceived organizational support and employee diligence, commitment, and innovation. Journal of Applied Psychology, 75(1), 51-59.

Eisenberger, R., Huntington, R., Hutchison, S., \& Sowa, D. (1986). Perceived organizational support. Journal of Applied Psychology, 71, 500-507. http://dx.doi.org/10.1037/0021-9010.71.3.500

Emerson, D. (2013). Organizational Culture, Job Satisfaction and Turnover Intentions: The Mediating Role of Perceived Organizational Support. Virginia Commonwealth University, Dissertations Publishing.

Emerson, R. M. (1972). Exchange theory, part I: A psychological basis for social exchange. In J. Berger, M. Zelditch, \& B. Anderson (Eds.), Sociological theories in progress (Vol. 2, pp. 38-57). Boston: Houghton Mifflin.

Emerson, R. M. (1976). Social exchange theory. In A. Inkeles, J. Coleman, \& N. Smelser (Eds.), Annual review of sociology (Vol. 2, pp. 335-362). Palo Alto, CA: Annual Reviews.

Etzioni, A. (1961). A comparative analysis of complex organizations. New York: Free Press.

Farh, J., Earley, P., \& Lin, S. (1997). Impetus for action: A cultural analysis of justice and organizational citizenship behavior in Chinese society. Administrative Science Quarterly, 421-444. http://dx.doi.org/10.2307/2393733

Farndale, E., Ruiten, J.V., Kelliher, C., \& Hope-Hailey, V. (2011). The influence of perceived employee voice on organizational commitment: An exchange perspective. Human Resource Management, 50(1), 113-129.

Gavino, M.C., Wayne, S.J., \& Erdogan, B. (2012). Discretionary and transactional human resource practices and employee outcomes: The role of perceived organizational support. Human Resource Management, 51(5), 665-686. http://dx.doi.org/10.1002/hrm.21493

Gong, Y., \& Chang, S. (2008). Institutional antecedents and performance consequences of employment security and career advancement practices: Evidence from the people's republic of China. Human Resource Management, 47(1), 33-48. http://dx.doi.org/10.1002/hrm.20196

Gouldner, A. W. (1960). The norm of reciprocity: A preliminary statement. American Sociological Review, 25, 161-178. http://dx.doi.org/10.2307/2092623

Harrison, D. A., Newman, D. A., \& Roth, P. L. (2006). How important are job attitudes? Meta-analytic comparisons of integrative behavioral outcomes and time sequences. Academy of Management Journal, 49, 305-325. http://dx.doi.org/10.5465/AMJ.2006.20786077

Hausknecht, J.P., Hiller, N.J., \& Vance, R.J. (2008). Work-unit absenteeism: Effects of satisfaction, commitment, labor market conditions, and time. Academy of management journal, 51(6), 1223-1245. http://dx.doi.org/10.5465/AMJ.2008.35733022

Herkman, D.R., Bigley, G.A., \& Hereford, J.F. (2009). Combined effects of organizational and professional identification on the reciprocity dynamic for professional employees. Academy of management journal, 52(3), 506-526. http://dx.doi.org/10.5465/AMJ.2009.41330897

Hofstede, G. (1984). The cultural relativity of quality of life concept. Academy of Management Review, 9(3), 389-398.

Homans, G. C. (1958). Social behavior as exchange. American Journal of Sociology, 63, 597-606.

Hulpia, H. (2009). The relationship between the perception of distributed leadership in secondary schools and teachers' and teacher leaders' job satisfaction and organizational commitment. School Effectiveness and School Improvement, 26(3), 565-575.

Iverson, R.D., \& Roy, P. (1994). A causal model of behavioral commitment: evidence from a study of Australian blue-collar employees. Journal of Management, 20(1), 15-41. http://dx.doi.org/10.1177/014920639402000102

Jokisaari, M., \& Nurmi, J-E. (2009). Change in newcomers' supervisor support and socialization outcomes after organizational entry. Academy of Management Journal, 52(3), 527-544.

Kirkman, B. L., Chen, G., Farh, J.-L., Chen, Z. X., \& Lowe, K.B. (2009). Individual power distance orientation and follower reactions to transform leaders: A cross-level, cross-cultural examination. Academy of Management Journal, 52(4), 744-764. http://dx.doi.org/10.5465/AMJ.2009.43669971

Kirkman, B., Lowe, K., \& Gibson, C. (2006). A quarter century of Culture's Consequences: a review of empirical research incorporating Hofstede's cultural values framework. Journal of International Business Studies, 37(3), 285-315. http://dx.doi.org/10.1057/palgrave.jibs. 8400202 
Klein, H.J., Molloy, J.C., \& Brinsfield, C.T. (2012). Reconceptualizing workplace commitment to redress a stretched construct: Revising assumptions and confounds. Academy of Management Review, 37(1), 130-151.

Kuvaas, B. (2008). An exploration of how the employee-organization relationship affects the linkage between perception of developmental human resource practices and employee outcomes. Journal of Management Studies, $45,1-25$.

Lee, K., \& Allen, N.J. (2002). Organizational citizenship behavior and workplace deviance: the role of affect and cognitions. Journal of Applied Psychology, 87, 131-42. http://dx.doi.org/10.1037/0021-9010.87.1.131

Lian, L., \& Tiu, L. (2012). Leadership styles and organizational citizenship behavior: The mediating effect of subordinates' competence and downward influence tactics. Journal of Applied Business and Economics, 13(2), 59-96.

Logan, M.S., \& Ganster, D.C. (2007). The Effects of Empowerment on Attitudes and Performance: The Role of Social Support and Empowerment Beliefs. Journal of Management Studies, 44(8), 1523-1550.

Mathieu, J., \& Hamel, D. (1989). A cause model of the antecedents of organizational commitment among professionals and non-professionals. Journal of Vocational Behavior, 34, 299-317.

Mayer, R. C., \& Davis, J. H. (1999). The effect of the performance appraisal system on trust for management: A field quasi-experiment. Journal of Applied Psychology, 84, 123-136.

Meyer, J. P. (2009). Commitment in a changing world of work. In H. J. Klein, T. E. Becker, \& J. P. Meyer (Eds.), Commitment in organizations: Accumulated wisdom and new directions (pp. 37-68). New York: Routledge/Taylor and Francis.

Meyer, J. P., \& Allen, N. J. (1991). A three-component conceptualization of organizational commitment. Human Resource Management Review, 1, 61-89. http://dx.doi.org/10.1016/1053-4822(91)90011-Z

Meyer, J. P., \& Herscovitch, L. (2001). Commitment in the workplace: Toward a general model. Human Resource Management Review, 11, 299-326. http://dx.doi.org/10.1016/S1053-4822(00)00053-X

Meyer, J. P., Becker, T. E., \& Vandenberghe, C. (2004). Employee commitment and motivation: A conceptual analysis and integrative model. Journal of Applied Psychology, 89, 991-1007.

Meyer, J., Stanley, D., Herscovitch, L., \& Topolnytsky. (2002). Affective, continuance, and normative commitments to the organization: A meta-analysis of antecedents, correlates, and consequences. Journal of Vocational Behavior, 61, 20-52. http://dx.doi.org/10.1006/jvbe.2001.1842

Michaels, P. (1994). An expanded conceptual framework on organizational commitmentand job satisfaction for salesforce management. Journal of Business and Society, 7(1), $42-67$.

Morrison, E. W. (1994). Role definition and organizational citizenship behavior: The importance of the employee's perspective. Academy of Management Journal, 37, 1543-1567. http://dx.doi.org/10.2307/256798

Mowday, R., Steers, R. M., \& Porter, L. (1979). The measurement of organizational commitment. Journal of Vocational Behavior, 14(2), 224-247. http://dx.doi.org/10.1016/0001-8791(79)90072-1

Organ, D. W. (1988). Organizational Citizenship Behavior: The "good soldier" Syndrome. Lexington, MA: Lexington Books.

Organ, D. W., \& Ryan, K. (1995). A meta-analytic review of attitudinal and dispositional predictors of organizational citizenship behavior. Personnel Psychology, 48, 775-788. http://dx.doi.org/10.1111/j.1744-6570.1995.tb01781.x

Organ, D. W., Podsakoff, P. M., \& MacKenzie, S. B. (2006). Organizational Citizenship Behavior: Its Nature, Antecedents, and Consequences. Thousand Oaks, CA: Sage.

Podsakoff, P. M., MacKenzie, S. B., Moorman, R. H., \& Fetter, R. (1990). Transformational leader behaviors and their effects on followers' trust in leader, satisfaction, and organizational citizenship behavior. Leadership Quarterly, 1, 107-142. http://dx.doi.org/10.1016/1048-9843(90)90009-7

Podsakoff, P. M., Mackenzie, S. B., Paine, J., \& Bacharach, D. (2000). Organizational citizenship behaviors: a critical review of the theoretical and empirical literature and suggestions for future research. Journal of Management, 26, 513-63. http://dx.doi.org/10.1177/014920630002600307 
Rasheed, A., Jehanzeb, K., \& Rasheed, M. (2013). An Investigation of the Antecedents of Organizational Citizenship Behavior: Case of Saudi Arabia. International Journal of Psychological Studies, 5(1), 128-138.

Rhoades, L. (2001). Reciprocation of perceived organizational support. Journal of Applied Psychology, 86, 42-51.

Rhoades, L., \& Eisenberger, R. (2002). Perceived organizational support: A Review of the literature. Journal of Applied Psychology, 87, 698-714. http://dx.doi.org/10.1037/0021-9010.87.4.698

Rhoades, L., Eisenberger, R., \& Armeli, S. (2001). Affective commitment to the organization: The contribution of perceived organizational support. Journal of Applied Psychology, 86, 825-836.

Rich, B.L., Lepine, J.A., \& Crawford, E.R. (2010). Job engagement: Antecedents and effects on job performance. Academy of Management Journal, 53(3), 617-635. http://dx.doi.org/10.5465/AMJ.2010.51468988

Riggle, R., Edmondson, D., \& Hansen, J. (2009). A meta-analysis of the relationship between perceived organizational support and job outcomes: 20 years of research. Journal of Business Research, 62(10), 1027-1030. http://dx.doi.org/10.1016/j.jbusres.2008.05.003

Riketta, M. (2005). Organizational identification: A meta analysis. Journal of Vocational Behavior, 66, 358-384.

Ristig, K. (2009). The impact of perceived organizational support and trustworthiness on trust. Managerial Research Review, 32(7), 659-669.

Sako, M. (1992). Prices, quality, and trust: Inter-firm relations in Britain and Japan. Cambridge University Press, Cambridge. http://dx.doi.org/10.1017/CBO9780511520723

Salancik, G., \& Pfeffer, J. (1978). A Social Information Processing Approach to Job Attitudes and Task Design. Administrative Science Quarterly, 23, 224-253. http://dx.doi.org/10.2307/2392563

Shore, L. M., \& Wayne, S. J. (1993). Commitment and employee behavior: Comparison of affective commitment and continuance commitment with perceived organizational support. Journal of Applied Psychology, 78, 774-780. http://dx.doi.org/10.1037/0021-9010.78.5.774

Singh, J., \& Rhodes, G. (1994). Boundary role ambiguity in marketing oriented positions: A multidimensional multifaceted operationalization. Journal of Marketing Research, 31, 328-338.

Snape, E, \& Redman, T. (2010). HRM Practices, Organizational Citizenship Behaviour, and Performance: A Multi-Level Analysis. Journal of Management Studies, 47(7), 1219-1247.

Sun, L-Y., Aryee, S., \& Law, K. S. (2007). High-performance human resource practices, citizenship behavior, and organizational performance: A relational perspective. Academy of Management Journal, 50(3), 558-577.

Swaminathan, S., \& Jawaher, P. (2013). Job satisfaction as a predictor of organizational citizenship behavior. Global Journal of Business Research, 7(1), 71-80.

Tsui, A. S., \& Wu, J. B. (2005). The new employment relationship versus the mutual investment approach: Implications for human resource management. Human Resource Management, 44, 115-121.

Tubre, T. C., \& Collins, J. M. (2000). Jackson and Schuler (1985) revisited: A meta-analysis of the relationships between role ambiguity, role conflict, and job performance. Journal of Management, 26, 155-169.

Turner, J. C. (1991). Social influence. Milton Keynes, U.K.: Open University Press.

Ueda, Y. (2012). Effects of job involvement on importance evaluation of organizational citizenship behavior. International Journal of Business and Society, 13(1), 77-89.

van Dick, R., Christ, O., Stellmacher, J., Wagner, U., Ahlswede, O., Grubba, C., ... Tissington, P. A. (2004). Should I stay or should I go? Explaining turnover intentions with organizational identification and job satisfaction. British Journal of Management, 15, 351-360. http://dx.doi.org/10.1111/j.1467-8551.2004.00424.x

Williams, L., \& Anderson, S. (1991). Job satisfaction and organizational commitment as predictors of organizational citizenship and in-role behaviors. Journal of Management, 17, 601-617.

Wright, T. A., \& Bonett, D. G. (2002). The moderating effects of employee tenure on the relation between organizational commitment and job performance: A meta-analysis. Journal of Applied Psychology, 87, 1183-1190. http://dx.doi.org/10.1037/0021-9010.87.6.1183

Zhang, Z., Wang, M., \& Shi, J. (2012). Leader-follower congruence in proactive personality and work outcomes: The mediating role of leader-member exchange. Academy of Management Journal, 55(1), 111-130. 